Kumawula, Vol. 3, No.3, Desember 2020, Hal 484 - 491 DOI: https://doi.org/10.24198/kumawula.v3i3.29635

ISSN 2620-844X (online)

Tersedia online di http://jurnal.unpad.ac.id/kumawula/index

\title{
LINGUISTIK KULTURAL SEBAGAI PENGUNGKAP KEARIFAN LOKAL DALAM PENINGKATAN LITERASI DI PESANTREN MANBA'UL ULUM TASIKMALAYA
}

\author{
Ani Rachmat ${ }^{1^{*}}$, Ferry P Pakpahan ${ }^{2}$, Upik Rafida ${ }^{3}$ \\ ${ }^{1}$ Universitas Padjadjaran \\ ${ }^{2}$ Universitas Padjadjaran \\ ${ }^{3}$ Universitas Padjadjaran
}

*Korespondensi : ani.rachmat@unpad.ac.id

\begin{abstract}
The current flow of information cannot be stopped, like a virus that infects and spreads through various communication media, especially the internet. Therefore, it is necessary to strengthen literacy for internet users, so as not to fall into and be influenced by misleading information. Literacy is a concept that has a complex, dynamic meaning, is continuously interpreted and defined in various ways and points of view. The purpose of this PPM is to strengthen the literacy skills of junior high school level students in Ponpes Manba'ul Ulum, Tasikmalaya, which is based on knowledge of health and linguaculture. The method used is community education in the form of distance seminars, given the Covid-19 Pandemic situation. The results of this PPM show an increase and strengthening of the literacy of students, this is evident from the various questions asked by students in the question and answer session.
\end{abstract}

Keywords: information; Linguaculture; Literacy

\begin{abstract}
ABSTRAK
Arus infomasi saat ini tidak dapat dibendung, bagaikan virus yang menginfeksi dan menular melalui berbagai media komunikasi, terutama internet. Oleh karena itu diperlukan penguatan literasi pada masyarakat pengguna internet, agar tidak terjerumus dan terpengaruh oleh informasi yang menyesatkan. Literasi merupakan sebuah konsep yang memiliki makna kompleks, dinamis, terus ditafsirkan dan didefinisikan dengan berbagai cara dan sudut pandang. Makna dasar literasi sebagai kemampuan baca-tulis merupakan pintu utama bagi pengembangan makna literasi secara lebih luas. Tujuan PPM ini adalah untuk menguatkan kemampuan literasi siswa setingkat SMP di Ponpes Manba'ul Ulum, Tasikmalaya yang berbasis pada pengetahuan kesehatan dan linguakultur. Metode yang digunakan adalah pendidikan masyarakat dengan cara kombinasi daring dan luring, mengingat situasi pandemi Covid-19. Hasil dari PPM ini menunjukan adanya peningkatan dan penguatan literasi pada siswa, hal ini terbukti dari berbagai pertanyaan yang dilontarkan siswa dalam sesi tanya-jawab.
\end{abstract}

\section{PENDAHULUAN}

Literasi merupakan aktivitas yang secara tidak sadar telah dilakukan oleh manusia sepanjang hidupnya. Setiap saat mereka belajar untuk menerima informasi baru sebagai tambahan pengetahuan, dan menggunakan persediaan informasi yang dimiliki untuk mengatasi persoalan yang dihadapi dalam hidupnya (Susanti \& Permana, 2017)
Dalam diskusi kelompok terpumpun (DKT) Gerakan Literasi Nasional (GLN) Tahun 2019, Menteri Pendidikan dan Kebudayaan (Mendikbud) saat itu, Muhadjir Effendy, menyampaikan bahwa ruh dari semua gerakan pendidikan adalah literasi, dan mengingatkan agar makna literasi jangan direduksi sekadar membaca buku saja. Dikatakan bahwa literasi itu tidak hanya membaca buku saja, namun dengan membaca seseorang memiliki 
perspektif baru, lalu dilanjutkan dengan membuat karya. Proses itu terjadi terus menerus sepanjang hayat (www.kemdikbud.go.id).

Gerakan literasi merupakan suatu gerakan yang digagas oleh Kementerian Pendidikan dan Kebudayaan pada tahun 2015 yang awalnya timbul akibat keprihatinan terhadap rendahnya kemampuan literasi dan minat baca masyarakat Indonesia, dan cara yang digunakan untuk memperoleh literasi adalah melalui pendidikan.

Iriantara (2009:5) menjelaskan bahwa kini literasi bukan hanya berhubungan dengan kemampuan membaca dan menulis teks saja, karena kini "teks" sudah diperluas maknanya sehingga mencakup juga "teks" dalam bentuk visual, audiovisual dan dimensi-dimensi komputerisasi, sehingga di dalam "teks" tersebut secara bersama-sama muncul unsurunsur kognitif, afektif, dan intuitif (Iriantara, 2009).

Kemajuan teknologi yang sangat pesat berpengaruh pada meningkatnya jumlah pengguna internet khususnya yang menggunakan internet untuk mengakses media sosial (Nasution, Jati, \& Setia, 2019). Media sosial saat ini tidak hanya dipandang sebagai ajang bersosialisasi di dunia maya semata, namun sudah berkembang menjadi ajang menuangkan ide-ide dalam pribadi sesorang yang berkaitan dengan banyak aspek serta membagikannya kepada orang lain (Mauludin, M.Ali; Alim, Syahirul; Sari, 2017). Melalui media sosial, penggunanya dapat mengakses banyak saluran dari berbagai bidang seperti politik, ekonomi, hukum, pendidikan, budaya, maupun kesehatan (Susanti, Gunawan, \& Sukaesih, 2019).

Gerakan literasi tidak dapat dibangun secara instan dan perlu dilakukan secara kontinyu, sehingga diperlukan adanya campur tangan atau dukungan dari pemerintah. Gerakan literasi tidak bisa dilakukan secara sepihak, namun perlu juga didukung pihak lain (Asmoro, Bramantyo Tri ; Sari, 2020).

Bahasa dan budaya selalu saling berkaitan, bahasa merupakan produk budaya yang tidak tampak wujudnya, tidak dapat disentuh atau diraba dengan indera, namun bahasa berperan sebagai alat penyimpan kebudayaan. Jika produk budaya yang berwujud dinamakan artefakt, maka bahasa sebagai produk abstrak disebut mentefakt. Bahasa tidak hanya berfungsi sebagai alat komunikasi, tapi sebagai akumulasi dari ilmu budaya, karena di dalam bahasa tersimpan tradisi, sejarah, dan budaya suatu bangsa. Linguakulturologi merupakan jembatan dalam aplikasi analisis kontak bahasa dan budaya. Triadic bahasa-bangsa-budaya adalah fokus utama dalam penelitian linguistik kultural. (Vorobyov, 2008)

\section{METODE}

Metode yang digunakan dalam PPM ini adalah pendidikan masyarakat, yaitu memberikan pengetahuan tentang literasi media dan kesehatan dengan pendekatan linguistik kultural kepada siswa tingkat SMP di Pondok Pesantra Manba'ul Ulum, Tasikmalaya. Edukasi adalah segala upaya yang direncanakan untuk mempengaruhi orang lain baik individu, kelompok maupun masyarakat sehingga mereka melakukan apa yang diharapkan oleh pelaku pendidikan (Notoatmojo, 2003). Dalam kaitannya dengan pendidikan bahasa dan budaya diharapkan para siswa di Pondok Pesantren ini dapat memahami dan mengaplikasikan pengetahuan dalam kehidupan sehari-hari.

Sehubungan dengan kondisi dan situasi pandemi, teknis pelaksanaannya adalah dengan menggelar teleseminar. Pihak pesantren merasa kesulitan jika harus mengikuti kegiatan daring secara penuh sehingga diputuskan dengan cara kombinasi daring dan luring. Pemberi materi berada di Bandung, tepatnya di rumah masingmasing, sedangkan para peserta berada di kompleks pesantren, didampingi oleh para pelaksana teknis. Teleseminar dilaksanakan menggunakan platform zoom. Siswa dibagi dalam dua kelas yaitu satu kelas laki-laki dan satu kelas perempuan. Masing-masing kelas terdiri atas 16 siswa. Setiap siswa dilengkapi dengan pelindung wajah dan kegiatan dilaksanakan sesuai dengan protokol kesehatan yang diberlakukan. Kegiatan ini telah direkam 
dan disiarkan secara langsung di channel youtube.

\section{HASIL DAN PEMBAHASAN}

Pondok Pesantren Manba'ul Ulum didirikan pada tahun 1918 oleh KH. Zaenal Abidin atas permintaan masyarakat setempat. Manba'ul ulum artinya sumber ilmu, dengan penamaan ini pendiri pondok pesantren berharap bahwa tempat tersebut menjadi sumber ilmu pengetahuan dan para santrinya dapat menjadi orang yang mampu mengamalkan ilmunya. Sejak wafatnya KH. Zaenal Abidin pada tahun 1974 pesantren ini dilanjutkan oleh putranya, KH. Endang Sambas Faqih, dan seterusnya, hingga sekarang dipimpin oleh K. Drs. Asep Ahmad Yani. Pada tanggal 28 Maret 1980 Ponpes ini menjadi Yayasan yang bergerak di bidang sosial dan pendidikan yang bertujuan untuk mencerdaskan kehidupan bangsa dan mengembangkan manusia seutuhnya, yaitu yang memiliki pengetahuan, keterampilan, sehat jasmani dan rohani, berkepribadian yang mantap dan mandiri, serta bertanggung jawab (Yani, 2020).

Misi dari Pondok Pesantren Manba'ul Ulum adalah: mewujudkan pembelajaran yang inovatif, kreatif, dan dinamis; mewujudkan nilai-nilai budaya untuk kehidupan berbangsa dan bernegara; mewujudkan kebersihan dan kenyamanan lingkungan (Yani, 2020). Untuk mendukung mewujudkan misi tersebut, kami dari kelompok PPM Unpad mencoba menerjemahkannya dengan memberikan teleseminar penyuluhan mengenai penguatan literasi dalam bidang kesehatan dan kebudayaan, yang dikaitkan dengan situasi terkini yakni pandemi Covid-19.

Teleseminar dilaksanakan pada tanggal 25 Agustus 2020. Pada bagian pertama teleseminar diawal dengan pemaparan mengenai kesehatan, berkaitan dengan pandemi Covid-19. Tim PPM kami dibantu oleh ahli kesehatan dari RS Cibabat, Cimahi, Dr. Jeffry Iman Gunardi, dr.,Sp.OG. Penjelasan mengenai cara menjaga kesehatan diri sendiri dan orang lain dipaparkan secara sederhana namun sangat informatif. Misalnya tentang penggunaan jenis masker yang benar. Selama ini kita menduga bahwa masker yang dilengkapi dengan lubang udara (berkatup) akan membantu kita bernapas dengan nyaman, tapi ternyata itu adalah masker yang harus dihindari. Selain masker, belakangan ini juga marak pemakaian pelindung wajah (face shield). Menurut dokter Jeffry, pelindung wajah ini fungsinya lebih diperuntukkan untuk melindungi wajah dari sentuhan tangan kita sendiri yang biasa kita lakukan tanpa kita sadari. Tangan kita adalah salah satu sumber pembawa virus, oleh karena itu, sangat dianjurkan untuk sering mencuci tangan. Atribut pelindung diri dari virus yang utama tetaplah masker. Selanjutnya dijelaskan pula tentang tes swab secara ringan. Dalam penjelasannya, dokter Jeffry mengibaratkan virus (antigen) sebagai penjahat, dan jika penjahat itu masuk, dia akan teridentifikasi, ditandai dengan keluarnya antibodi. Sehingga pada dasarnya jika seseorang diduga terpapar virus, lalu melakukan rapid test atau swab test, maka hasilnya akan terlihat dari keluar atau tidaknya antibodi. Jika antibodi orang tersebut keluar, artinya ada virus di tubuhnya, jika tidak keluar, berarti tidak terpapar virus (CDC, Kemenkes RI, 2020).

Setelah pemaparan dari dokter ini, siswa diberi kesempatan untuk bertanya. Pertanyaanpertanyaan seputar virus Covid-19 ini sangat menarik, di antaranya adalah apakah pencegahan penularan virus dapat dilakukan dengan keyakinan agama, misalnya dengan berwudlu atau pemakaian cadar bagi perempuan? Berwudlu merupakan kebiasaan yang sangat baik, karena ada kegiatan membersihkan tangan, wajah, kaki dengan air. Tentu saja akan sangat membantu dalam mencegah penularan virus, karena salah satu anjurannya adalah untuk selalu mencuci tangan, lebih baik lagi jika ditambahkan sabun cuci. Sementara pemakaian cadar bagi perempuan, adalah sebuah kebudayaan suatu kelompok bangsa atau agama tertentu, dan hal ini pun suatu langkah yang baik, karena secara prinsipnya cadar setara dengan masker, yaitu sebagai penutup sebagian wajah. Pertanyaan lainnya adalah seperti apa perbedaan pandemi 
Covid-19 sekarang ini dengan pandemi virus flu burung atau ebola, dan mengapa penyebarannya begitu luas dan cepat. Pada saat pandemi flu burung terjadi, apabila seseorang terpapar virus, maka orang tersebut langsung jatuh sakit, sedangkan pada kasus Covid-19, orang yang terpapar virus tidak selalu langsung jatuh sakit. Pada kasus Covid-19, orang yang terpapar virus justru bisa menjadi pembawa (carrier) virus tersebut. Hal ini lebih membahayakan karena membuat penyebarannya semakin meluas mengingat orang tersebut tidak menyadari bahwa dirinya sudah terkena virus tersebut (CDC, Kemenkes RI, 2020).

Sesi kedua teleseminar membahas tentang bahasa dan budaya melalui meme lucu sekait dengan pandemi Covid-19. Humor yang ditampilkan dalam teks dan gambar memberikan ilustrasi yang menarik dan menghibur di tengah kondisi yang sulit ini. Humor dipercaya dapat mengurangi beban pikiran sehingga jiwa dan raga tetap sehat.

Sejak munculnya berita tentang pandemi Covid-19 yang berawal di kota Wuhan, Tiongkok, banyak istilah baru yang digunakan di berbagai media, seperti lockdown, karantina, ODP, PDP, OTD, new normal, PSBB, tatanan baru, social distancing, physical distancing, jaga jarak, isolasi mandiri, PCR, rapid test, swab test, droplet, hand sanitizer, dan masih banyak lagi kata-kata asing yang tidak dapat dipahami oleh semua orang.

Istilah lockdown menjadi sangat populer, walaupun bukan merupakan kata yang baru. Namun pada kenyataannya, tidak semua orang memahami arti kata tersebut ataupun mengetahui cara penulisannya. Hal ini terlihat dari berbagai variasi yang tampak pada gambar: lauk daun (gambar 1), lock don't (gambar 2), down load (gambar 3), dan yang lebih parah menjadi kata London (gambar 4 dan 5). Istilah lain yang sering didengar selama pandemi ini adalah karantina yang berasal dari kata quarantine. Dalam gambar 5, muncul kata Argentina yang diduga ini berasal dari kata karantina karena terdapat bunyi yang hampir serupa yaitu “-ntina”'.
Dari banyaknya variasi bentuk kata yang salah kaprah akibat mengandalkan pendengaran saja, menunjukkan kurangnya pemahaman dari individu yang menulisnya. Kami dari tim PPM FIB Unpad kemudian mengajak para peserta seminar untuk mencermati istilah asing ini dengan mencari maknanya dalam kamus dua bahasa yaitu bahasa Inggris-Indonesia. Selain itu juga diperkenalkan cara untuk mencari arti kata dalam kamus elektronik yang ada di internet.

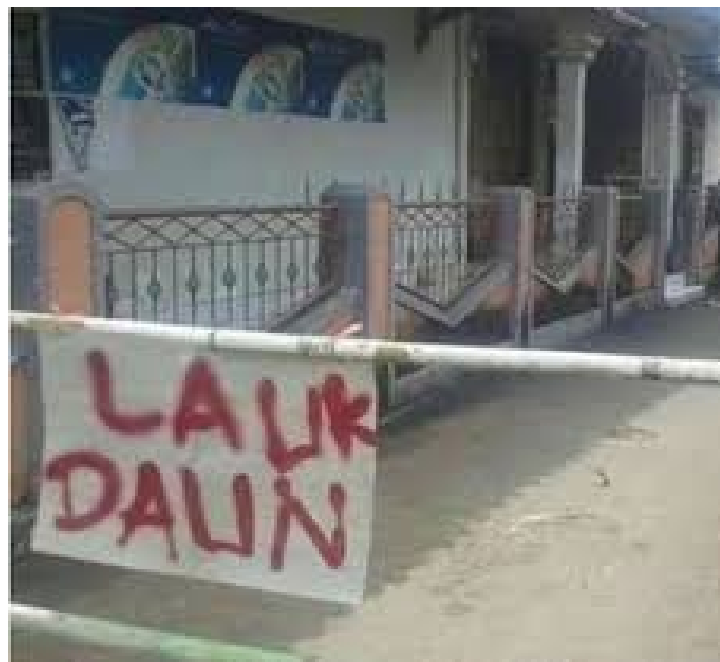

Gambar 1.

https://www.indomeme.id/meme-virus-corona/

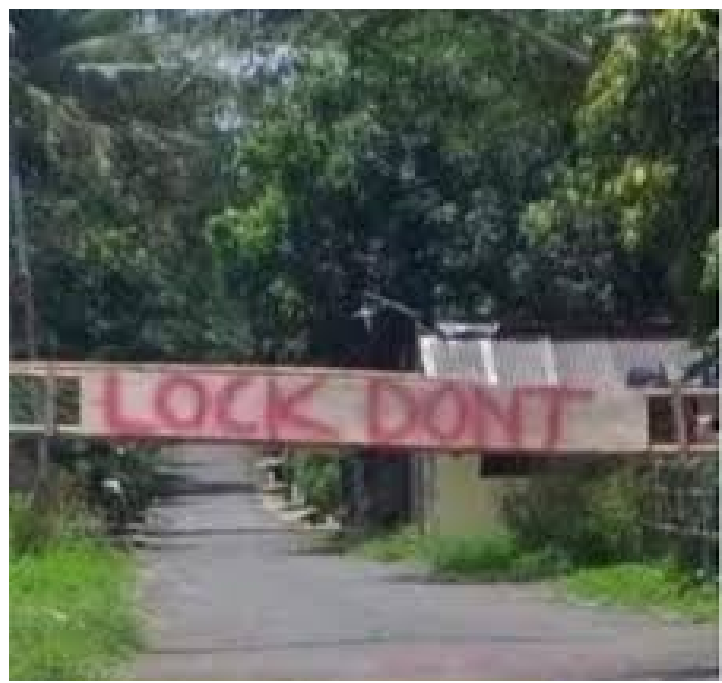

Gambar 2.

https://www.indomeme.id/meme-virus-corona/ 


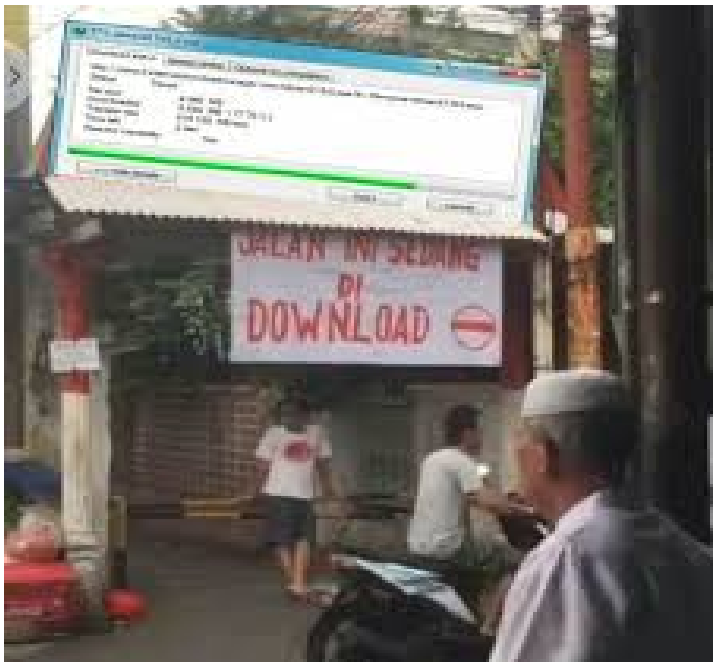

Gambar 3.

https://www.indomeme.id/meme-virus-corona/

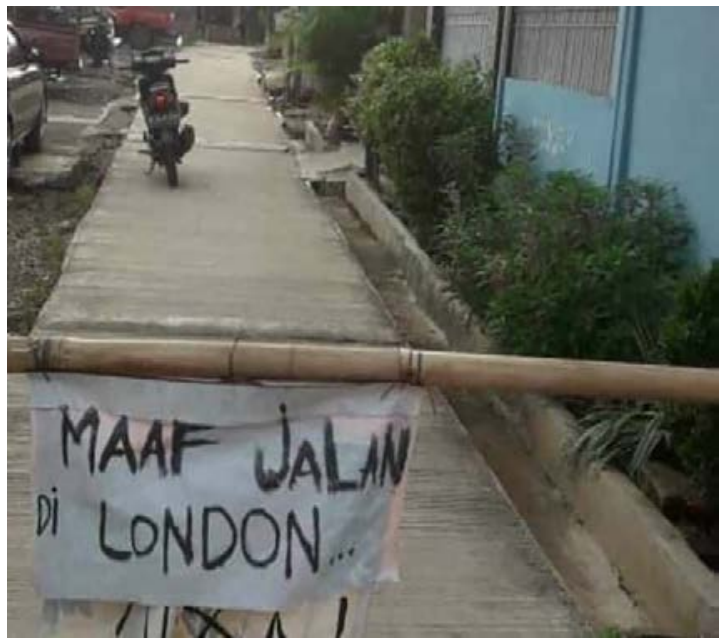

Gambar 4.

https://today.line.me/id/v2/article/lXOkMv

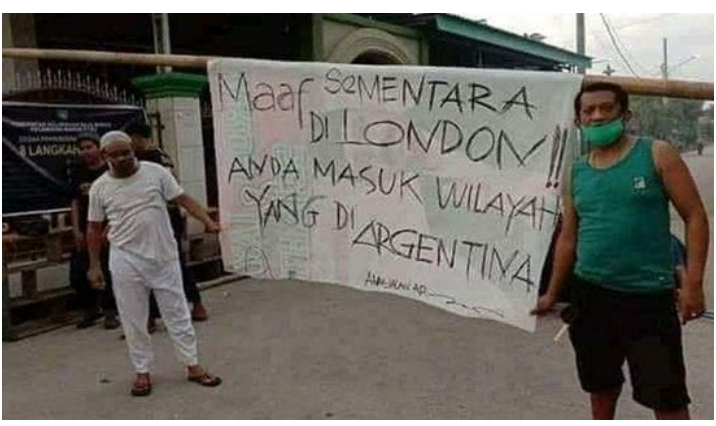

Gambar 5.

https://www.suara.com

Hal di atas berbeda dengan teks berikut ini:

"Bro, apa bedanya PHYSICAL distancing sama SOCIAL distancing?"

"Physical distancing untuk anak FISIKA (IPA). Social distancing untuk anak SOSIAL (IPS)”
“Ooh ... lha kamu ikut yang mana, bro?”

"Gak ada. Aku kan anak BAHASA."

Teks percakapan di atas menunjukkan adanya kreativitas dalam berbahasa. Kreativitas ini muncul dari fenomena yang ada di dunia pendidikan kita, yakni adanya pembagian bidang peminatan untuk siswa tingkat menengah atas, yakni kelompok IPA, IPS, dan Bahasa. Dari teks percakapan ini, tentu kita langsung paham bahwa teks ini dibuat dengan tujuan untuk berkelakar atau menghibur. Karena di sini jelas adanya korelasi antara istilah yang sedang populer saat ini dengan istilah yang telah lama mereka kenal: phisycal distancing berkorelasi dengan kelompak siswa Fisika (IPA) sedangkan social distancing dikorelasikan dengan kelompok siswa IPS meskipun sebetulnya tidak ada korelasi makna antara kedua kedua istilah tersebut.

Kami mencoba menawarkan lagi bentuk meme verbal yang lainnya, seperti berikut ini:

\begin{tabular}{|l|l|}
\hline \multicolumn{1}{|c|}{ DEWA - 19 } & \multicolumn{1}{c|}{ COVID - 19 } \\
\hline Kirana & Corona \\
\hline Cukup Siti Nurbaya & $\begin{array}{l}\text { Cukup di rumah } \\
\text { Saja }\end{array}$ \\
\hline Separuh Nafas & Sesak Nafas \\
\hline Hadapi dg Senyuman & Hadapi dg Was2 \\
\hline $\begin{array}{l}\text { Sedang Ingin } \\
\text { Bercinta }\end{array}$ & Sedang Jaga Jarak \\
\hline Bukan Cinta Biasa & Bukan Virus Biasa \\
\hline Risalah Hati & Susah Hati \\
\hline
\end{tabular}

Para siswa peserta teleseminar cukup mengenal grup musik Dewa-19. Dalam meme verbal ini tampak kreativitas pembuatnya dengan membandingkan grup musik dengan pandemi. Keduanya memiliki kemiripan dalam berbagai hal sehingga dicocok-cocokan atau istilah yang dikenal anak sekarang adalah “cocokologi”. Pertama dapat dilihat pada penggunaan nama dimana keduanya menggunakan angka 19. Pun pada judul-judul lagu Dewa-19 memiliki unsur kemiripan dalam hal bunyi, seperti Kirana dengan Corona, dan unsur-unsur leksikal untuk judul yang lainnya, dengan cara substitusi salah satu kata. Di bagian 
ini, siswa diajak untuk melihat secara kritis bentuk-bentuk kata yang digunakan baik dalam judul lagu maupun dalam hal yang dikaitkan dengan covid. Misalnya dalam penulisan kata nafas dalam 'Separuh Nafas' dan 'Sesak Nafas'. Menurut Ejaan Bahasa Indonesia (EBI) dan kamus bahasa Indonesa - KBBI, penulisan yang benar adalah menggunakan huruf $/ \mathrm{p} /$ bukan /f/ , jadi seharusnya ditulis napas bukan nafas.

Contoh lainnya adalah seperti berikut ini: Kenapa namanya Covid? Karena asalnya dari China.

Kalau dari Betawi namanya Bangvid.

Kalau dari Jawa namanya Masvid.

Dari Sunda namanya Kangvid.

Dari Minang namanya David.

Meme verbal ini sangat viral di media sosial dan pembuatnya adalah para anonim sebagaimana meme lainnya. Di sini kita tentu menyadari betapa telitinya si pembuat humor ini dengan mengaitkan kata covid dengan memenggal suku kata pertama "Co-“ sebagai sinonim dari sebutan kakak laki-laki "koko”, sehingga memunculkan paradigma lainnya dari panggilan-panggilan yang ada di daerah-daerah di Indonesia. Jika diteruskan maka akan semakin panjang, karena banyak sekali istilah kekerabatan untuk memanggil kakak laki-laki dalam berbagai bahasa daerah di Indonesia.

Bangsa Indonesia adalah bangsa yang sangat menjunjung tinggi kebersamaan dan gotong royong, sehingga muncul peribahasa bersatu kita teguh, bercerai kita runtuh. Dari peribahasa ini muncul plesetannya karena adanya pandemi covid menjadi bersatu kita mati, bercerai kita selamat (gambar 6). Hal ini menunjukkan adanya kecerdasan dalam memilih kata dan kalimat dan daya kreasi dengan menggali dari berbagai hal yang kecil yang sudah dikenal sejak lama.

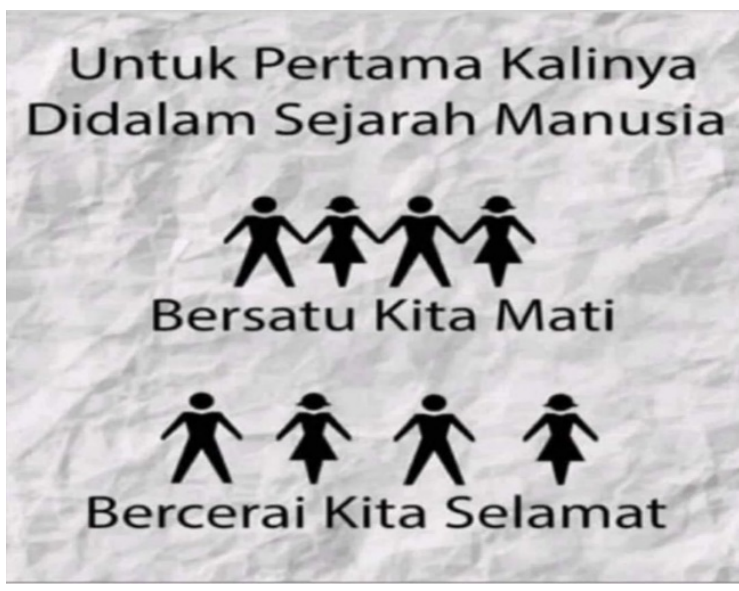

Gambar 6.

https://dairipers.com/hindari-panik-denganmeme-kocak-masa-pandemik-corona/

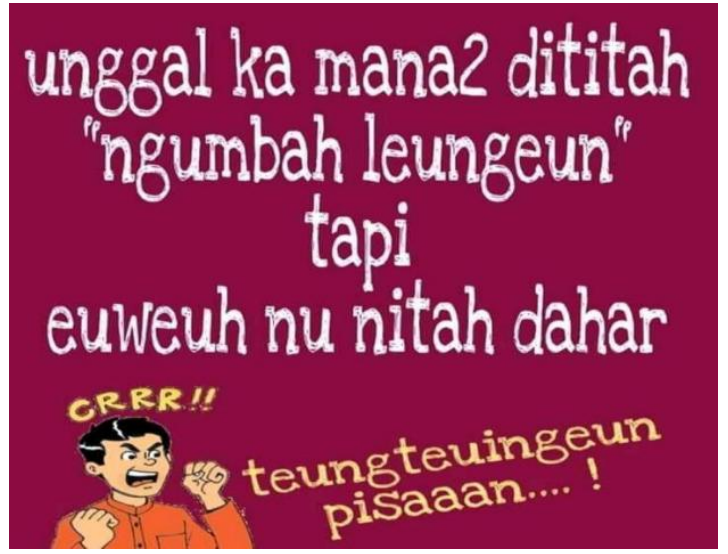

Gambar 7

https://www.dara.co.id/santuy-mang-inilima-meme-corona-yang-dijaminngakak.html

Meme humor tidak hanya ditemukan dalam bahasa Indonesia, tetapi juga dalam bahasa daerah seperti dalam bahasa Sunda (Gambar 7). Dalam budaya Sunda, dan budaya Indonesia, juga di seluruh dunia, mencuci tangan bukan lah hal istimewa. Sejak kecil kita semua diajari untuk mencuci tangan sebelum makan, jadi tidak heran jika ada meme verbal seperti gambar di atas: unggal kamana-mana dititah “ngumbah leungeun”, tapi euweuh nu nitah dahar, teungteuingeun pisaaaaan...! 'kemana saja kita pergi selalu disuruh "mencuci tangan', tapi ga ada yang nyuruh makan, tega nian...!'. Kalimat di atas mengungkapkan bahwa aktivitas “mencuci tangan” seolah-olah menjadi budaya baru yang muncul sejak adanya 
pandemi Covid-19 dan sering mencuci tangan ini bukan berarti akan diberi makan.

Unsur budaya yang menarik yang muncul dalam meme kocak adalah tentang kebiasaan kerokan di Indonesia. Dalam meme (gambar 8.) ini dimunculkan tokoh kartun Spongebob yang naive, sehingga dialog yang terjadi menunjukkan ketidakpahaman tentang pandemi Covid-19. Dari contoh ini, kami mengajak siswa untuk memahami lebih dalam akan bahaya penyakit ini dan cara pencegahan dan pengobatannya yang benar.

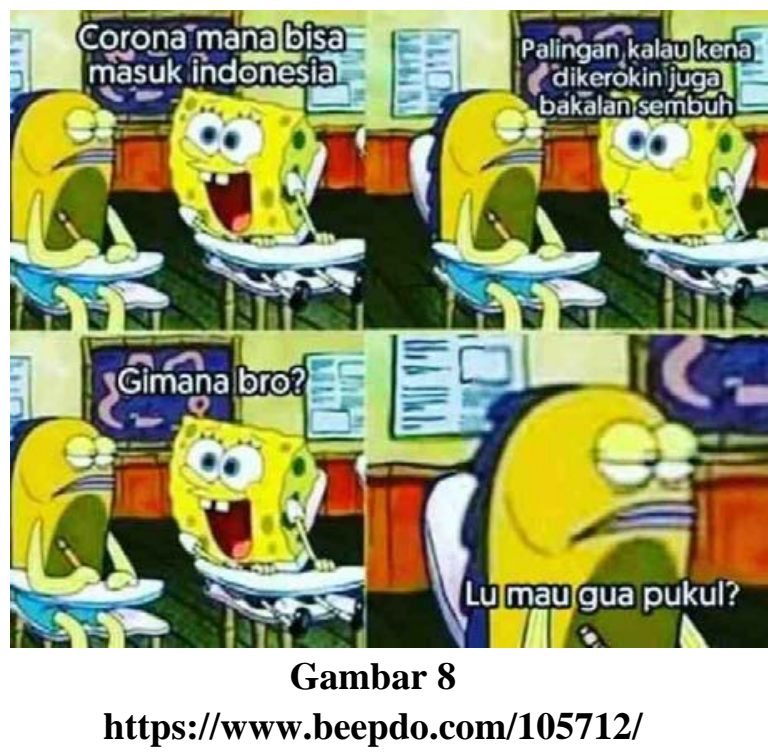

\section{SIMPULAN}

Berdasarkan hasil analisis dan pembahasan sebelumnya dapat disimpulkan bahwa tingkat literasi siswa setingkat SMP, khususnya bagi para siswa peserta kegiatan PPM Dosen di Ponpes Manba'ul Ulum menunjukkan peningkatan. Artinya PPM dosen ini telah memberi kontribusi mengenai pemahaman kesehatan dan budaya/bahasa pada kegiatan literasi linguakultur. Hal ini terbukti dengan berbagai pertanyaan yang diajukan dalam sesi tanya-jawab dengan para pemateri. Meskipun kadang-kadang pertanyaan yang disampaikan sangat naif, bahkan lucu dan tidak terpikirkan sebelumnya oleh kami, misalnya, pertanyaan tentang penularan Covid-19 melalui binatang. Indikator peningkatan dalam bidang kesehatan secara komprehensif adalah perolehan informasi terkait Protokol Kesehatan yang menjadikan mereka lebih patuh untuk mengaktualisasikannya dalam keseharian seperti penggunaan masker yang benar, cuci tangan secara higienis, menjaga jarak sampai menghindari kerumunan.

Selain itu, siswa semakin sadar akan penggunaan Bahasa Indonesia yang baik dan benar yang sesuai dengan Ejaan Bahasa Indonesia. Di samping itu, mereka lebih berhati-hati dalam penggunaan bahasa asing dan mengetahui bagaimana caranya mengecek bahasa asing tersebut sebelum digunakan. Peningkatan perolehan dalam bidang bahasa ditunjukkan oleh pemahaman mereka pada diksi kata, penulisan ejaan yang sesuai kaidah, juga dapat merespon atau bersikap bijak dan benar terhadap meme yang lucu, bahkan pada kesalahkaprahan berbahasa yang marak beredar di tengah masyarakat

\section{DAFTAR PUSTAKA}

Asmoro, Bramantyo Tri ; Sari, D. K. (2020). Meningkatkan Literasi Siswa Desa Sukodono Kecamatan Dampit, Kabupaten Malang melalui Revitalisasi Perpustakaan Desa. Kumawula, 3(2), 280-288.

Iriantara, Y. (2009). Literasi Media: Apa, Mengapa, dan Bagaimana. Bandung: Simbiosa Rekatama Media.

Mauludin, M.Ali; Alim, Syahirul; Sari, V. P. (2017). Cerdas Dan Bijak Dalam Memanfaatkan Media Sosial Di Tengah Era Literasi Dan Informasi. Jurnal Aplikasi Ipteks Untuk Masyarakat, 6(1), 1-4.

Nasution, Z., Jati, A. K. N., \& Setia, S. (2019). PELATIHAN ETIKA BERBAHASA BAGI SISWA UNTUK MENINGKATKAN KETERAMPILAN BERKOMUNIKASI DI MEDIA SOSIAL. Kumawula: Jurnal Pengabdian Kepada Masyarakat, 2(2).

Notoatmojo, S. (2003). Pendidikan dan Perilaku Kesehatan. Jakarta: Rineka Cipta. 
Susanti, S., Gunawan, W., \& Sukaesih. (2019). Pengembangan Pemasaran Bordir dan Kelom Geulis Tasikmalaya Melalui Media Sosial. Jurnal Kumawula: Jurnal Pengabdian Kepada Masyarakat, 2(3), 248-261.

https://doi.org/http://10.24198/kumawula. vli3.25256

Susanti, S., \& Permana, R. S. M. (2017). Pembelajaran Literasi Budaya Sunda pada Peserta Didik Sekolah Dasar Utami Kab. Garut, Jawa Barat. Jurnal Aplikasi Ipteks Untuk Masyarakat, 6(2), 106-110.

Vorobyov, V. V. (2008). Lingvokul'turologia. Moscow: RUDN.

Yani, Asep A. (2020). Visi, Misi Pondok Pesantres Mambaul Ulum. (Unpublished)

CDC Kemenkes RI, 2020, bahan presentasi ppt. (Unpublished)

\section{Sumber Gambar}

https://dairipers.com/hindari-panik-denganmeme-kocak-masa-pandemik-corona/

https://www.indomeme.id/meme-virus-corona/

https://today.line.me/id/v2/article/lXOkMv

https://www.suara.com/otomotif/2020/04/21/1 50958/10-potret-imbauan-warga-saattutup-akses-jalanan-karena-coronakocak-abis?page $=$ all

https://www.beepdo.com/105712/psbb-jakartaberakhir-simak-lagi-meme-coronasebuah-sindiran-buat-kamu-yang-masihcuek

https://www.dara.co.id/santuy-mang-ini-limameme-corona-yang-dijaminngakak.html 